\title{
Importance of micronutrients in bone health of monogastric animals and techniques to improve the bioavailability of micronutrient supplements - A review
}

\author{
Santi Devi Upadhaya ${ }^{1}$ and In Ho Kim ${ }^{1, *}$
}

\author{
* Corresponding Author: In Ho Kim \\ Tel: +82-41-550-3652, Fax: +82-41-565-2949, \\ E-mail: inhokim@dankook.ac.kr \\ 'Department of Animal Resource and Science, \\ Dankook University, Cheonan 31116, Korea \\ ORCID \\ Santi Devi Upadhaya \\ https://orcid.org/0000-0002-3801-4964 \\ In Ho Kim \\ https://orcid.org/0000-0001-6652-2504
}

Submitted Dec 10, 2019; Revised Jan 30, 2020; Accepted Mar 9, 2020

\begin{abstract}
Vitamins and minerals categorized as micronutrients are the essential components of animal feed for maintaining health and improving immunity. Micronutrients are important bioactive molecules and cofactors of enzymes as well. Besides being cofactors for enzymes, some vitamins such as the fat-soluble vitamins, vitamin $\mathrm{A}$ and $\mathrm{D}$ have been shown to exhibit hormone-like functions. Although they are required in small amount, they play an influential role in the proper functioning of a number of enzymes which are involved in many metabolic, biochemical and physiological processes that contribute to growth, production and health. Micronutrients can potentially have a positive impact on bone health, preventing bone loss and fractures, decreasing bone resorption and increasing bone formation. Thus, micronutrients must be provided to livestock in optimal concentrations and according to requirements that change during the rapid growth and development of the animal and the production cycle. The supply of nutrients to the animal body not only depends on the amount of the nutrient in a food, but also on its bioavailability. The bioavailability of these micronutrients is affected by several factors. Therefore, several technologies such as nanoparticle, encapsulation, and chelation have been developed to improve the bioavailability of micronutrients associated with bone health. The intention of this review is to provide an updated overview of the importance of micronutrients on bone health and methods applied to improve their bioavailability.
\end{abstract}

Keywords: Bone Health; Bioavailability; Micronutrient; Minerals; Vitamins

\section{INTRODUCTION}

Micronutrients are essential elements required by organisms in small quantities for normal body function e.g. vitamin and minerals. Vitamins are organic micronutrients that are necessary in minute amounts for the normal function of many metabolic pathways, gene regulation and immune functions [1]. Vitamins play an influential role in the regulation of body functions, promoting resistance to diseases thereby keeping the body healthy. The deficiency of a vitamin can lead to disease or death. Vitamins are classified as fat-soluble and water-soluble. Fat-soluble vitamins including vitamins A, D, E, and $\mathrm{K}$ are vitamins stored in the adipose tissue and released as per the need of the body. $\mathrm{B}$ vitamins (thiamine, riboflavin, pyridoxine, pantothenic acid, niacin, folic acid, choline and vitamin $B_{12}$ ) and vitamin $\mathrm{C}$ are water-soluble vitamins. As water passes through the body, it carries out watersoluble vitamins. Thus, these vitamins need to be consumed every day by farm animals. However, vitamin C can be synthesized in tissues by animals under normal conditions [1] but under different stress conditions, it should be provided to the animals. Unlike monogastric animals, water-soluble B vitamins are made by microorganisms in the rumen of a 
ruminant animal [2].

Minerals are inorganic nutrients that are required in small quantities but participate in orchestration of different biological processes that drive normal growth, development, and function. Minerals are also essential for the formation of bones and teeth; as essential constituents of body fluids and tissues; as components of enzyme systems and for normal nerve function. Minerals are classified as macrominerals or microminerals. Macrominerals including calcium, chlorine, magnesium, phosphorus, potassium, sodium, and sulfur are needed in relatively higher amount $(\mathrm{g} / \mathrm{kg}$ body weight dimension) than microminerals or trace minerals such as chromium, cobalt, copper, fluorine, iodine, iron, manganese, molybdenum, selenium, zinc, silicon and boron. It is well-established that the deficiency or inadequate amount of minerals in the diet may impair productivity, immune functions and health $[3,4]$.

Considering the massive changes in growth potential and management in commercial pig and poultry production over the coming decades and how these may influence the vitamin nutrition of animals, a new concept of optimum vitamin nutrition (OVN) has become essential. Thus, various sources have recommended vitamin doses so as to meet the needs of body in poultry (Tables 1,2) and pigs as shown in (Tables 3 , 4). An appropriate and specific supply during the specific physiological phases of animals leads to positive results that go beyond the initial objective of preventing deficiency. Thus, with the rapid growth and development of animals and their production cycle, the supplementation of micronutrients must be adjusted according to their requirements to meet their body needs as a means of enhancing growth and reproductive performance, improving immunity indices, maximize mineral digestibility, improve bone health and egg shell quality.

\section{MICRONUTRIENTS IN BONE HEALTH}

Bony skeleton is an important organ that not only provides mobility, support and protection to the body but also acts as a reservoir of major essential minerals such as $\mathrm{Ca}$ and $\mathrm{P}$. The growth of the skeleton, its response to mechanical forces, and its role as a mineral storehouse are all dependent on the proper functioning of a number of circulating hormones that are responsive to changes in blood calcium, phosphorus as well as other minerals. Genetic abnormalities, nutritional deficiencies, hormonal disorders, lack of exercise, immobilization can result in the formation of weak, poorly mineralized bone having negative effects on bone mass and strength leading to osteoporosis and osteomalacia [5].

An important modifiable factor in the prevention of osteoporosis (disease in which the density and quality of bone are reduced) as well as in bone development and maintenance of bone mass is nutrition [6]. Micronutrients and macronutrients can influence bone health $[7,8]$. Clinical trials showed micronutrients can potentially have a positive impact on bone health, preventing bone loss and fractures, decreasing bone resorption and increasing bone formation [9]. In addition to

Table 1. Recommended vitamin levels for broiler starter to finisher period by different sources

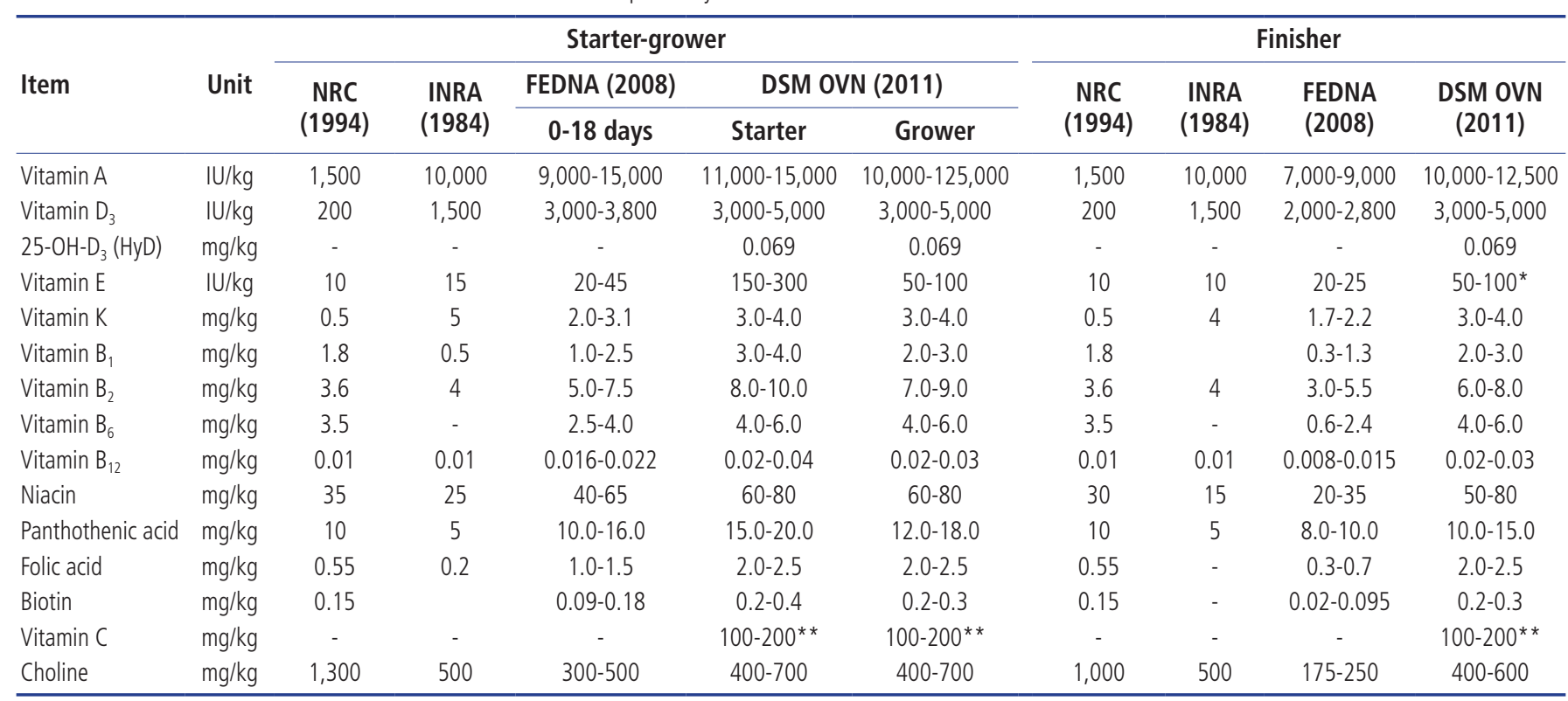

NRC, National Research Council; INRA, Institut National de Recherche Agronomique (National Institute for Agricultural Research); FEDNA, Fundación Española para el Desarrollo de la Nutrición Animal (Foundation for the Development of Animal Nutrition); OVN, optimum vitamin nutrition.

${ }^{*}$ Additional $150 \mathrm{mg} / \mathrm{kg}$ for meat quality.

** Recommended under heat stress.

Adapted from DSM Nutritional Product Limited 2012, 5m Publication, UK [99]. 
Table 2. Recommended vitamin levels for laying hens by genetic companies and different sources

\begin{tabular}{|c|c|c|c|c|c|c|c|c|}
\hline Item & Unit & $\begin{array}{l}\text { ISA brown } \\
(2010)\end{array}$ & $\begin{array}{l}\text { Hy-line } \\
(2010)\end{array}$ & $\begin{array}{c}\text { Lohman } \\
\text { (2009) }\end{array}$ & $\begin{array}{l}\text { DSM (OVN) } \\
(2011)\end{array}$ & $\begin{array}{l}\text { FEDNA } \\
(2008)\end{array}$ & $\begin{array}{l}\text { Maximum level } \\
\text { in literature }\end{array}$ & Responses \\
\hline Vitamin A & $\mathrm{IU} / \mathrm{kg}$ & 10,000 & 8,800 & 10,000 & $8,000-12,000$ & $8,000-10,000$ & 12,000 & Better immune response in heat stress [100] \\
\hline Vitamin $D_{3}$ & $\mathrm{IU} / \mathrm{kg}$ & 2,500 & 3,300 & 2,500 & $3,000-4,000$ & $2,000-3,000$ & $6,000 / 15,000$ & Improved bone strength in laying hens [101] \\
\hline $25-\mathrm{OH}-\mathrm{D}_{3}(\mathrm{HyD})$ & $\mathrm{mg} / \mathrm{kg}$ & - & 0.055 & - & 0.069 & - & 0.069 & Improved egg production [102] \\
\hline Vitamin E & $\mathrm{IU} / \mathrm{kg}$ & 20 & 16.5 & $10.0-30.0$ & $20-30$ & $8.0-20$ & 500 & Reduced chronic stress [103] \\
\hline Vitamin K & $\mathrm{mg} / \mathrm{kg}$ & 3.0 & 2.2 & 3.0 & $2.5-3.0$ & $1.4-2.1$ & 10 & Improved bone strength in layers and pullets [104] \\
\hline Vitamin $B_{2}$ & $\mathrm{mg} / \mathrm{kg}$ & 5.0 & 5.5 & 4.0 & $5.0-7.0$ & $4.0-6.0$ & 8.8 & Enhanced production [105] \\
\hline Vitamin $\mathrm{B}_{6}$ & $\mathrm{mg} / \mathrm{kg}$ & 5.0 & 3.3 & 3.0 & $3.5-5$ & $1.5-3.0$ & 6.0 & Prevent bone deformities[106] \\
\hline Vitamin $B_{12}$ & $\mathrm{mg} / \mathrm{kg}$ & 0.015 & 0.022 & 0.015 & $0.015-0.025$ & $0.009-0.015$ & 0.036 & \\
\hline Niacin & $\mathrm{mg} / \mathrm{kg}$ & 40 & 28 & 30 & $30-50$ & $18-35$ & $250-1,550$ & $\begin{array}{l}\text { Enhanced feed efficiency, improved shell quality and } \\
\text { reduced yolk cholesterol [107] }\end{array}$ \\
\hline Panthothe-nic acid & $\mathrm{mg} / \mathrm{kg}$ & 12 & 6.5 & 8.0 & $8.0-12.0$ & $7.0-10.0$ & - & \\
\hline Folic acid & $\mathrm{mg} / \mathrm{kg}$ & 0.75 & 0.6 & 0.5 & $1.0-1.5$ & $0.2-0.6$ & 1.5 & Performance improvement in old hens [108] \\
\hline Biotin & $\mathrm{mg} / \mathrm{kg}$ & 0.05 & 0.055 & 0.025 & $0.1-0.15$ & $0.035-0.08$ & - & \\
\hline Vitamin C & $\mathrm{mg} / \mathrm{kg}$ & 100 & - & - & $100-200 *$ & - & 2,000 & Improved bone shell and mineralization [109] \\
\hline Choline & $\mathrm{mg} / \mathrm{kg}$ & 1,400 & 110 & 400 & $300-500$ & $150-250$ & $1,500-2,000$ & Reduced fat deposition in liver [110] \\
\hline
\end{tabular}

OVN, optimum vitamin nutrition; FEDNA, Fundación Española para el Desarrollo de la Nutrición Animal (Spanish Foundation for the Development of Animal Nutrition).

* Recommended under heat stress condition.

Adapted from DSM Nutritional Product Limited [99].

their passive roles as substrate for bone formation, dietary calcium and protein play active roles in bone metabolism, other vitamins and minerals are also needed for metabolic processes related to bone, directly or indirectly. Micronutrients involved in bone health are as follows:

\section{Calcium and phosphorous}

The most abundant cation in the body is calcium. About 99\% of calcium $(\mathrm{Ca})$ exists in the mineral phase of bone and the remaining $1 \%$ is present within the extracellular and intracellular fluids [6]. Likewise, about $85 \%$ of body phosphorous $(\mathrm{P})$ in phosphate form is present in bone. Hormonal and physicochemical factors stimulate $\mathrm{Ca}$ and phosphate to interact in many fundamental processes in the body and $\mathrm{Ca}$ and $\mathrm{P}$ are complementary for bone growth and development [10]. For sustaining mineral homeostasis and bone metabolism, the ratio of $\mathrm{Ca}$ to $\mathrm{P}$ is critical [11]. Lagos et al [12] determined that if $\mathrm{P}$ is provided in the required level of $0.33 \%$ in pigs, the

Table 3. Recommended vitamin levels for weaner-finisher pigs by various sources

\begin{tabular}{|c|c|c|c|c|c|c|c|c|c|c|c|c|c|c|c|}
\hline \multirow{3}{*}{ Item } & \multirow{3}{*}{ Unit } & \multicolumn{7}{|c|}{ NRC (2012) } & \multirow{2}{*}{\multicolumn{3}{|c|}{$\begin{array}{c}\text { DanBred } \\
\text { Weaner-Finisher }(k g)\end{array}$}} & \multirow{2}{*}{\multicolumn{4}{|c|}{$\begin{array}{c}\text { DSM (OVM, 2011) } \\
\text { Weaner-Finisher (kg) }\end{array}$}} \\
\hline & & \multicolumn{3}{|c|}{ Piglets (kg) } & \multicolumn{4}{|c|}{ Growing-Finisher (kg) } & & & & & & & \\
\hline & & $5-7$ & $7-11$ & $11-25$ & $25-50$ & $50-75$ & $75-100$ & $100-135$ & $<9$ & $9.0-30$ & $30-100$ & $<5$ & $5.0-30$ & $30-70$ & $>70$ \\
\hline Vitamin A & IU/kg & 2,200 & 2,200 & 1,750 & 1,300 & 1,300 & 1,300 & 1,300 & 8,000 & 5,000 & 4,000 & $\begin{array}{l}10,000- \\
20,000\end{array}$ & $\begin{array}{l}10,000- \\
15,000\end{array}$ & $\begin{array}{l}7,000- \\
10,000\end{array}$ & $\begin{array}{l}5,000- \\
8,000\end{array}$ \\
\hline Vitamin $D_{3}$ & IU/kg & 220 & 220 & 200 & 150 & 150 & 150 & 150 & 800 & 500 & 400 & $\begin{array}{l}1,800- \\
2,000\end{array}$ & $\begin{array}{l}1,800- \\
2,000\end{array}$ & $\begin{array}{l}1,500- \\
2,000\end{array}$ & $\begin{array}{l}1,000- \\
1,500\end{array}$ \\
\hline $25-\mathrm{OH}-\mathrm{D}_{3}(\mathrm{HyD})$ & $\mathrm{mg} / \mathrm{kg}$ & - & - & - & - & - & - & - & - & - & - & 0.05 & 0.05 & 0.05 & 0.05 \\
\hline Vitamin E & IU/kg & 16 & 16 & 11 & 11 & 11 & 11 & 11 & 130 & 130 & 36 & $100-150$ & $100-150$ & $60-100$ & $60-100$ \\
\hline Vitamin K & $\mathrm{mg} / \mathrm{kg}$ & 0.5 & 0.5 & 0.5 & 0.5 & 0.5 & 0.5 & 0.5 & 2.0 & 2.0 & 2.0 & $8.0-10$ & $5.0-6.0$ & $2.0-4.0$ & $2.0-4.0$ \\
\hline Vitamin $B_{1}$ & $\mathrm{mg} / \mathrm{kg}$ & 1.5 & 1.0 & 1.0 & 1.0 & 1.0 & 1.0 & 1.0 & 2.0 & 2.0 & 2.0 & $3.5-5.5$ & $3.0-5.0$ & $2.0-3.0$ & $1.0-2.0$ \\
\hline Vitamin $B_{2}$ & $\mathrm{mg} / \mathrm{kg}$ & 4.0 & 3.5 & 3.0 & 2.5 & 2.0 & 2.0 & 2.0 & 4.0 & 4.0 & 2.0 & $10.0-15.0$ & $10.0-15.0$ & $7.0-10.0$ & $6.0-10.0$ \\
\hline Vitamin $B_{6}$ & $\mathrm{mg} / \mathrm{kg}$ & 7.0 & 7.0 & 3.0 & 1.0 & 1.0 & 1.0 & 1.0 & 3.0 & 3.0 & 3.0 & $6.0-8.0$ & $6.0-8.0$ & $2.5-4.5$ & $2.0-3.5$ \\
\hline Vitamin $B_{12}$ & $\mathrm{mg} / \mathrm{kg}$ & 0.02 & 0.017 & 0.015 & 0.01 & 0.005 & 0.005 & 0.005 & 0.02 & 0.02 & 0.02 & $0.05-0.07$ & $0.04-0.06$ & $0.03-0.05$ & $0.03-0.05$ \\
\hline Niacin & $\mathrm{mg} / \mathrm{kg}$ & 30 & 30 & 30 & 30 & 30 & 30 & 30 & 20 & 20 & 20 & $60-80$ & 33-55 & $20-40$ & $20-40$ \\
\hline Panthothenic acid & $\mathrm{mg} / \mathrm{kg}$ & 12 & 10 & 9.0 & 8.0 & 7.0 & 7.0 & 7.0 & 10 & 10 & 10 & $30-50$ & $25-45$ & $25-45$ & $25-45$ \\
\hline Folic acid & $\mathrm{mg} / \mathrm{kg}$ & 0.3 & 0.3 & 0.3 & 0.3 & 0.3 & 0.3 & 0.3 & - & - & - & $1.5-3.0$ & $1.5-2.5$ & $1.0-1.5$ & $0.5-1.0$ \\
\hline Biotin & $\mathrm{mg} / \mathrm{kg}$ & 0.08 & 0.05 & 0.05 & 0.05 & 0.05 & 0.05 & 0.05 & 0.02 & 0.02 & 0.1 & $0.20-0.04$ & $0.2-0.4$ & $0.15-0.30$ & $0.10-0.20$ \\
\hline Vitamin C & $\mathrm{mg} / \mathrm{kg}$ & - & - & - & - & - & - & - & - & - & - & $100-200$ & $100-200$ & 0 & 0 \\
\hline Choline & $\mathrm{mg} / \mathrm{kg}$ & 600 & 500 & 400 & 300 & 300 & 300 & 300 & - & - & - & $500-800$ & $250-400$ & $150-300$ & $100-200$ \\
\hline
\end{tabular}

NRC, National Research Council; OVN, optimum vitamin nutrition.

Adapted from DSM Nutritional Product Limited [99] and National Research Council [111]. 
Table 4. Recommended dietary vitamin levels for breeder pigs by various sources

\begin{tabular}{|c|c|c|c|c|c|c|c|c|c|}
\hline \multirow{2}{*}{ Item } & \multirow{2}{*}{ Unit } & \multicolumn{3}{|c|}{ NRC (2012) } & \multicolumn{2}{|c|}{ DanBred } & \multicolumn{3}{|c|}{ DSM (OVN, 2011) } \\
\hline & & Gestation & Lactation & Boars & Gestation & Lactation & Gilts & Sows & Boars \\
\hline Vitamin A & IU/kg & 4,000 & 2,000 & 4,000 & 8,000 & 8,000 & $10,000-12,500$ & $10,000-15,000$ & $10,000-15,000$ \\
\hline Vitamin $D_{3}$ & IU/kg & 800 & 800 & 200 & 800 & 800 & $1,800-2,000$ & $1,500-2,000$ & $1,500-2,000$ \\
\hline $25-\mathrm{OH}-\mathrm{D}_{3}(\mathrm{HyD})$ & $\mathrm{mg} / \mathrm{kg}$ & - & - & - & - & - & 0.05 & 0.05 & 0.05 \\
\hline Vitamin $\mathrm{E}$ & IU/kg & 44 & 44 & 44 & 36 & 150 & $80-100$ & $100-150$ & $100-150$ \\
\hline Vitamin K & $\mathrm{mg} / \mathrm{kg}$ & 0.5 & 0.5 & 0.5 & 2.0 & 2.0 & $1.5-3$ & $4.5-5$ & $4.5-5$ \\
\hline Vitamin $B_{1}$ & $\mathrm{mg} / \mathrm{kg}$ & 1.0 & 1.0 & 1.0 & 2.0 & 2.0 & $1.0-2.0$ & $2.0-2.5$ & $1.0-2.0$ \\
\hline Vitamin $B_{2}$ & $\mathrm{mg} / \mathrm{kg}$ & 3.75 & 3.75 & 3.75 & 5.0 & 5.0 & $6.0-10.0$ & $6.0-10.0$ & $6.0-10.0$ \\
\hline Vitamin $\mathrm{B}_{6}$ & $\mathrm{mg} / \mathrm{kg}$ & 1.0 & 1.0 & 1.0 & 3.0 & 3.0 & $3.5-5.5$ & $3.5-5.5$ & $3.5-5.5$ \\
\hline Vitamin $B_{12}$ & $\mathrm{mg} / \mathrm{kg}$ & 0.015 & 0.015 & 0.015 & 0.02 & 0.02 & $0.03-0.05$ & $0.03-0.05$ & $0.03-0.05$ \\
\hline Niacin & $\mathrm{mg} / \mathrm{kg}$ & 10 & 10 & 10 & 20 & 20 & $20.0-30.0$ & $25-45$ & $25-45$ \\
\hline Panthothenic acid & $\mathrm{mg} / \mathrm{kg}$ & 12 & 12 & 12 & 15 & 15 & $15-30$ & $30-35$ & $20-30$ \\
\hline Folic acid & $\mathrm{mg} / \mathrm{kg}$ & 1.3 & 1.3 & 1.3 & 1.1 & 1.1 & $3.5-5.5$ & $3.5-5.5$ & $3.5-5.5$ \\
\hline Biotin & $\mathrm{mg} / \mathrm{kg}$ & 0.2 & 0.2 & 0.2 & 0.02 & 0.02 & $0.30-0.50$ & $0.50-0.80$ & $0.50-0.80$ \\
\hline Vitamin C & $\mathrm{mg} / \mathrm{kg}$ & - & - & - & - & - & $200-300$ & $200-300$ & $200-500$ \\
\hline Choline & $\mathrm{mg} / \mathrm{kg}$ & 1,250 & 1,000 & 1,250 & - & - & $325-500$ & $500-800$ & $500-800$ \\
\hline
\end{tabular}

NRC, National Research Council; OVN, optimum vitamin nutrition.

Adapted from DSM Nutritional Product Limited [99] and National Research Council [111].

optimum ratio of Ca:P is $1.39: 1$ or $1.25: 1$ to maximize daily gain and gain: feed respectively whereas for the optimization of bone ash, the ratio is 1.66:1. The optimal levels of dietary standardized total tract digestible calcium for retention of calcium and phosphorus were suggested at or above $0.60 \%$ and $0.49 \%$ respectively [12]. The bone formation requirements that have a close connection with the health and welfare of the animals determine the need for $\mathrm{Ca}$ and P. For a proper functional musculoskeletal system, growth and performance traits should be combined with adequate bone formation [13]. Thus, the surpluses or deficiency of $\mathrm{Ca}$ and $\mathrm{P}$ have remarkable effects on bone mineral content and density, bone development and bone composition. The $\mathrm{Ca}$ and $\mathrm{P}$ dependent processes depend on the uptake, excretion and availability of these elements. Therefore, considerable attention has been paid to the regulation of plasma parathyroid hormone, calciumbinding protein, calcitriol/1, 25(OH) ${ }_{2} \mathrm{D}_{3}[14,15]$ and insulinlike growth factor-1 concentration [16]. Ca and P play a central role not only in the formation of bone during the growth of piglets, these minerals and associated endocrine factors are required for the development of soft tissues. In a pig study, Heyer et al [17] suggested that there exist links between dietary $\mathrm{P}$ and the immune system, indicating that the mineral nutrient is equally important for improved immune functions. A strong linkage of bone and immune system development is facilitated by regulatory processes in the bone marrow that control immune functions and hematopoiesis [18].

\section{Magnesium}

Magnesium is an essential cofactor in $80 \%$ of all cellular en- zymes and is an important contributor to bone health. About $60 \%$ of the body magnesium is found in bone and it makes up about $1 \%$ of the total bone mineral content [19]. It is necessary for the conversion of vitamin $\mathrm{D}$ into its active form [20]. The enzyme that is required for forming new calcium crystals, alkaline phosphatase, also requires magnesium for activation, and if its levels are low, abnormal bone crystal formation can result [21]. Even mild magnesium deficiency is reported to be a leading risk factor for osteoporosis [22]. Research has been done in recent years that shows osteoporosis can be a direct result of calcium that hasn't been metabolized by the body due to a lack of magnesium.

\section{Zinc}

Zinc is an important element in bone metabolism which is needed to produce the matrix of collagen protein threads upon which the bone-forming calcium-phosphorus compound is deposited. It acts as a co-factor in over 200 enzymatic reactions and plays a crucial role in bone health. Zinc also stimulates the production of enzymes responsible for the degradation and recycling of worn-out bits of bone protein. $\mathrm{Zn}$ may impact the normal physiological action of vitamin $\mathrm{D}$ on calcium metabolism and interfere with the anabolic activity of vitamin $\mathrm{D}$ on bone tissue $[23,24]$.

\section{Copper}

Copper is involved in many biological processes including enzymatic reactions and bone health. The formation of bone, mineralization of skeleton, and the integrity of the connective tissue are significantly influenced by copper [25,26]. Copper deficiency may result in impaired bone and cholesterol me- 
tabolism [27]. For the cross-linking of collagen fibrils, lysyl oxidase, a copper-containing enzyme is essential as it helps to increase the mechanical strength of the protein to form strong, flexible connective tissue [28]. Copper supplementation to rats suffering an ovariectomy-induced reduction of bone mass had a positive effect suggesting its therapeutic potential in osteoporosis [29].

\section{Silicon and boron}

Several studies demonstrated that silicon is also an essential trace mineral for normal bone development, cartilage growth, and improved bone quality [30,31]. Some evidence indicates the involvement of silicon with calcium metabolism and the formation and stabilization of the extracellular bone matrix $[32,33]$. It can regulate calcium turnover that influences the processes of bone calcification and decalcification [34]. Synergistic effects of calcium and silicon for the stimulation of bone formation have been reported by Maehira et al [35]. Incharoen et al [31] have also suggested that the supplementation of silicon into the diet as a mineral additive enhanced the bone and meat quality in broilers. The ability of silicon to reduce lameness in broilers has been detected in the studies by Short et al [36] and Nakhon et al [37].

Boron is increasingly recognized as an element that has an influence on bone health by stabilizing and extending the half-life of vitamin D and estrogen [38-40]. The supplementation of boron in the form of boric acid has been shown to increase bone strength in rats and laying hens [41,42]. In boron deficient rats, it was found that healing of the alveolar bone, a ridge of compact bone that contains the tooth sockets on the maxillae and mandible was inhibited indicating that boron also influences bone health.

\section{Vitamins}

Among vitamins, vitamin $\mathrm{D}$ is quite unique since it can be obtained from the diet as well as synthesized in the body from exposure to ultraviolet $\mathrm{B}$ radiation from sunlight. The form of vitamin $\mathrm{D}$ used in supplement products can be either vitamin $\mathrm{D}_{2}$ (ergocalciferol) or vitamin $\mathrm{D}_{3}$ (cholecalciferol). Vitamin $\mathrm{D}_{3}$ is also synthesized in the skin from 7-dehydrocholesterol under the influence of ultraviolet $\mathrm{B}$ radiation from sunlight through a two-step process in which the $\mathrm{B}$ ring is broken by UV light radiation forming pre- $\mathrm{D}_{3}$ that isomerizes to $\mathrm{D}_{3}$ in a thermo-sensitive process [43]. Endogenous synthesis, however, is considered the most available source of vitamin D [44]. Compared to what is typically consumed in the diet, higher amounts of vitamin $\mathrm{D}$ can be obtained from sun exposure. However, in intensive farming systems, animals are kept in close confinement and may not have enough exposure to sunlight leading to inadequate vitamin $\mathrm{D}$ synthesis. A deficiency in young pigs results in rickets, stiffness and lameness, enlargement of the joints and general unthriftiness.
In mature and market animals, bone fractures are common if vitamin $\mathrm{D}$ is deficient. Thus, supplemental vitamin $\mathrm{D}$ is needed for the efficient absorption and metabolism of calcium and phosphorus and therefore is required for normal calcification of bones [45]. The secretion of parathyroid hormone is regulated by vitamin $\mathrm{D}$ thereby stimulating several tissues with vitamin D receptors [46]. Regardless of origin, vitamin $\mathrm{D}$ is an inactive prohormone and must first be metabolized to its hormonal form before it can function. Thus, to generate the biologically active form, vitamin $\mathrm{D}$ needs to be processed further. This activation process occurs in 2 steps: i) within the liver, cholecalciferol is hydroxylated to 25-hydroxycholecalciferol $(25[\mathrm{OH}] 2 \mathrm{D})$ by the enzyme 25 -hydroxylase; and ii) within the kidney, 25-hydroxycholecalciferol is converted to $1,25(\mathrm{OH})_{2} \mathrm{D}$ by the enzyme $1 \alpha$ hydroxylase $[47,48]$. In human studies, it was demonstrated that each microgram of orally consumed 25-hydroxyvitamin $\mathrm{D}_{3}$ was 4.2 to 5 times more potent in raising serum $25(\mathrm{OH}) \mathrm{D}$ in older adults in winter than was an equivalent amount of vitamin $\mathrm{D}_{3}$ [44]. It has been reported that $25(\mathrm{OH}) \mathrm{D}_{3}$ is more active than vitamin $\mathrm{D}_{3}$ and allows more efficient utilization [49]. However, Garcia and coworkers [50], noted that the different metabolites $\mathrm{D}_{3}$, $25(\mathrm{OH}) \mathrm{D}_{3}, 1,25(\mathrm{OH})_{2} \mathrm{D}_{3}$, and $1 \alpha(\mathrm{OH}) \mathrm{D}_{3}$ used showed similar results for bone parameters in broiler chickens. A study by Amundson [51] indicated that sows femur's mechanical properties were improved with the inclusion of vitamin D to the diet. Besides bone health, vitamin $\mathrm{D}$ also has an influential role in the regulation of myogenic genes [52]. However, excessive amounts of vitamin $\mathrm{D}$ in the feed or as an injectable are harmful due to deposits of calcium in soft tissues [53].

The association between various $B$ vitamins $\left(B_{2}, B_{6}\right.$, folate, or $\mathrm{B}_{12}$ ) and a lower risk of osteoporosis are inconsistent among studies or across different $B$ vitamins. For instance, $B_{6}$ deficient rats had osteoporotic veins with cavities and less new bones [54] and vitamin $\mathrm{B}_{6}$ deficient chicks had decreased cortical thickness, osteoid in trabecular bone, reduced secondary ossification centers and coarse trabeculation [55]. However, no difference in bone strength, bone area was observed in vitamin $B_{12}$-deficient rats [56] and no significant difference in osteocalcin, callus stiffness and size was seen in folate and vitamin $\mathrm{B}_{{ }_{12}}$ deficient mice [57].

Vitamin $\mathrm{K}$ activates a protein called osteocalcin, which builds and heals bone [58]. Transcription and translation of osteocalcin gene are regulated by $1,25(\mathrm{OH})_{2} \mathrm{D}_{3}$ [59], but its ability to bind to calcium ions depends on the vitamin $\mathrm{K}$ [60]. In a review, Akbari and Rasouli-Ghahroudi [61] suggested that adding vitamin $\mathrm{K}$ as an adjunct to the bone materials may stimulate bone cells and their progenitors to produce native bone with promising results reflecting the importance of vitamin $\mathrm{K}$ in bone health. 


\section{BIOAVAILABILITY OF MICRONUTRIENTS (VITAMINS AND MINERALS)}

Regardless of whether micronutrients are consumed in the form of feed or supplements, it is believed that not $100 \%$ of the ingested nutrients will be absorbed because of bioavailability issues. Understanding nutrient bioavailability helps to optimize diets and set appropriate nutrient recommendations. The term bioavailability is used to refer to the sequential metabolic events of nutrient utilization, and it includes digestion, absorption, enzymatic transformation, and excretion [62]. To make the nutrient bioavailable, it should be bio-accessible [63]. Nutrients can be made bio-accessible by the processes of mastication and enzymatic digestion of the food in the mouth, followed by swallowing and mixing with acid and enzymes in the gastric juice, and absorption after finally being released into the small intestine, which is the major site of nutrient absorption [64]. Thus, first step is to liberate nutrients from food matrix and covert them to chemical forms which can then easily bind to and enter the gut cells.

Essential nutrients should be provided in appropriate amounts and in the forms that are biologically utilizable for the efficient production of livestock and poultry and the maintenance of their normal life functions [65-67]. Deficiencies of certain nutrients occur frequently in diets consisting of common feed ingredients, and these nutrients must be provided in a supplemental form. Degree of bioavailability influences not only dietary requirements but also tolerance of a nutrient. Thus, it is important to know the bioavailability of nutrients in both common feed ingredients and dietary supplements that may be used in animal feeding.

Numerous factors that influence the bioavailability of nutrients are the chemical form of nutrient; the nutrient matrix; the nutrient absorption enhancers and inhibitors; metabolic ability after absorption; state of health, genetic factors, age of the host; as well as other individual factors [68].

For instance, the bioavailability of lipid-soluble nutrients is significantly influenced by their physicochemical availability so as to be incorporated into mixed micelles during digestion. Upon ingestion and initial digestion within the stomach, there is a possibility of release of lipid-soluble components. The factors influencing the release include localization within the food matrix; physical break-up of the food; breakdown of the food particles through chemical and enzymatic reactions; and the presence of a suitable lipid phase in the form of emulsion droplets or free lipid [69].

The occurrence of competition for common binding sites or carriers has been reported in minerals having similar chemical properties. For example, iron, zinc, and copper are typical examples of competitive inhibitors [70]. Besides this, the nutritional status of host for specific micronutrients, notably iron, has a major effect on absorption. For instance, the status of vitamin A can decrease iron bioavailability by preventing hemoglobin formation [71]. In addition, the bioavailability of $\mathrm{Fe}$ is impaired due to the chelation of $\mathrm{Fe}$ with dietary polyphenols in the lumen of the intestine. Fe bioavailability can be enhanced by ascorbate which reduces ferric iron to the ferrous form of iron which is less reactive with phytate or polyphenols [72].

A number of host-related physiological factors influence the absorption and utilization of nutrients. Most of these factors are key participants in the body's homeostatic regulatory mechanisms such as nutritional status, stage of development, gastric and intestinal secretions, mucosal cell regulation, and gut microflora. The role of gastrointestinal (GI) factors is clearly seen in the absorptive pathway of vitamin $\mathrm{B}_{12}$. This vitamin requires gastric acid to be released from the gastric mucosa which then undergoes a sequence of binding to cobalophilin, release from cobalophilin, binding to the protein "intrinsic factor (IF)" and finally absorption of the intact IFvitamin $\mathrm{B}_{12}$ complex in the lower intestine [73]. The functional impairment of the gastric mucosa can compromise the production of IF and cobalophilin eventually inhibiting vitamin $\mathrm{B}_{12}$ bioavailability.

\section{Technologies for the improvement of supplemental micronutrient bioavailability}

Nano engineering and encapsulation/coating: Nano engineering ensures the development of materials with novel properties having wider range of applications and can be prepared from both organic and inorganic materials [74,75]. Nano- engineering of materials enhances their bioavailability by protecting them against chemical conditions in the GI tract, and allowing the controlled release within the GI tract or by an improved transfer through the intestinal wall [76,77]. The characteristics of nano-engineered materials affecting the final nutritional value include particle size, physical state of nano- materials and their surface properties [78].

Several encapsulated nanoparticles have been designed and tested for their potential use as delivery systems for vitamin $\mathrm{D}$ and vitamin $\mathrm{E}$ so as to optimize supplementation strategies thereby improving the health benefits via encapsulation, protection and/or controlled/sustained release [79-83]. Although $\mathrm{ZnO}$ and $\mathrm{Cu}$ salts in high doses as supplements to piglets' diet, stimulate piglets' daily gain and decrease feed conversion factor, the application of high concentrations of these metal additives could lead to an adverse effect on environment and public health hazard. In the meantime, $\mathrm{ZnO}$ applied at doses 2,500 to $3,000 \mathrm{mg} / \mathrm{kg}$ feed can contribute to the development of antimicrobial resistance and may modify piglets' immune response via the regulation and expression of related genes [83]. The application of nano sized $\mathrm{ZnO} / \mathrm{Cu}$ particles could notably reduce the dietary inclusion rate and 
environmental pollution while preserving the beneficial impact on pigs' health [84]. The degree of the reduction of piglet diarrhea incidence observed with low dose $\mathrm{ZnO}$ nanoparticles (600 mg Zn/kg) supplemented to the basal diet of weaning piglets as compared with that of high dose of traditional $\mathrm{ZnO}$ $(2,000 \mathrm{mg} \mathrm{Zn} / \mathrm{kg})$ has been suggested to be mediated by improving intestinal microbiota and inflammation response in piglets, and could contribute in reducing zinc environmental pollution [84]. Our study also demonstrated that lipid-matrix coated $\mathrm{ZnO}$ at a low dose could substitute for the conventional high dose $\mathrm{ZnO}$ in weaning pigs [85]. Vahjen et al [86] demonstrated that the new form of modified $\mathrm{ZnO}$ led to a reduction in bacterial growth in the GI tract more rapidly than analytical grade $\mathrm{ZnO}$ which was consistent with our study which demonstrated that the dietary supplementation with modified $\mathrm{ZnO}$ increased growth rate, bioavailability and reduced fecal scores in weanling pig [87].

Chelation: Chelation is the process in which organic molecules such as amino acids or peptides trap or encapsulate certain metal ions like $\mathrm{Ca}, \mathrm{Mg}, \mathrm{Fe}, \mathrm{Co}, \mathrm{Cu}, \mathrm{Zn}$, and Mn. Several bonds with a single metal ion can be formed with these organic molecules. The chelate creates compatibility between the two charges by encapsulating the positively charged nutrient and neutralizing it. The nutrient is then able to move freely into the animal body. Chelation allows nutrients to be absorbed by animals with ease if there is lack of competitive antagonism among minerals at the site of absorption. The bioavailability of mineral supplements ingested as mineral salts has been observed in animal studies $[88,89]$. Generally, the best sources of supplemental elements include sulfates, chlorides, phosphates, acetates, citrates and gluconates or carbonates of $\mathrm{Ca}$ and $\mathrm{Zn}$ whereas sulfides and oxides are generally poor sources of mineral elements [90]. Amino-acid chelates are reported to have significantly higher absorption rates in the intestine compared with soluble inorganic metal salts [91]. Jiao et al [92] demonstrated that increasing dose of zinc aspartic acid chelate $(0 \%, 0.1 \%, 0.2 \%, 0.3 \%)$ supplementation imparted beneficial effects on the performance and digestibility of nutrients in growing pigs. However, reported results regarding the bioavailability of $\mathrm{Zn}$ chelates and traditional inorganic forms are conflicting [93]. Guo and coworkers [94] demonstrated the enhancement of Ca absorption and significant increase in femur bone mineral density and femur Ca content in rats when $\mathrm{Ca}$ was supplemented in the form of $\mathrm{Ca}$ alginate nanoparticles loaded with collagen peptide chelated Ca suggesting that they could prevent Ca deficiency. In addition, Chen et al [95] demonstrated that a calciumchelating peptide complex prepared from tilapia skins could promote bone formation and an increase in bone collagen in mice via a better bioavailability of Ca. Zinc in the form of methionine hydroxy analog chelate zinc has been found to be more stable than other organic $\mathrm{Zn}$ forms and has higher bioavailability in broilers [96] and laying hens from 39 to 52 weeks of age [97]. In a trial with 120,000 broilers, Manangi et al [98] reported that supplementing the birds with reduced level of $\mathrm{Zn}$ (32 ppm), copper (8 ppm), and manganese (32 $\mathrm{ppm}$ ) as methionine hydroxy analogue chelates significantly improved footpads and reduced trace mineral excretion compared to birds fed higher levels of $\mathrm{Zn}(100 \mathrm{ppm}), \mathrm{Cu}$ (125 ppm), and Mn (90 ppm) suggesting that chelating technology enhances the bioavailability of nutrients.

\section{CONCLUSION}

The importance of micronutrients, for example, vitamins and minerals, in sufficient amounts needed for bone health of humans and animals is indisputable. Therefore, different technologies are currently being employed to improve the bioavailability of these micronutrients so as to ensure the optimal supplementation of these micronutrients for better health status including bone health and with an additional benefit of reducing their impact on the environment.

\section{CONFLICT OF INTEREST}

We certify that there is no conflict of interest with any financial organization regarding the material discussed in the manuscript.

\section{ACKNOWLEDGMENTS}

This study was supported by the research fund of Dankook University in 2020.

\section{REFERENCES}

1. Veum TL. Feed supplements: crystalline vitamins. In: Pond W, Ullrey D, Baer C, editors. Encyclopedia of animal science. 2nd Ed. Boca Raton, FL, USA: Taylor and Francis; 2011.

2. Mc Dowell LR. Vitamins in animal and human nutrition. 2nd Ed. Ames, IA, USA: Iowa State University Press; 2000.

3. Radwinska J, Zarczynska K. Effects of mineral deficiency on the health of young ruminants. J Elem 2014;19:915-28.

4. Wu D, Lewis ED, Pae M, Meydani SN. Nutritional modulation of immune function: analysis of evidence, mechanisms, and clinical relevance. Front Immunol 2019;9:3160. https://doi. org/10.3389/fimmu.2018.03160

5. Office of the Surgeon General (US). Bone health and osteoporosis: a report of the surgeon general. Rockville MD, USA: Office of the Surgeon General (US); 2004.

6. Pepa GD, Brandi ML. Microelements for bone boost: the last but not the least. Clin Cases Miner Bone Metab 2016;13:181-

5. https://doi.org/10.11138/ccmbm/2016.13.3.181

7. Saltman PD, Strause LG. The role of trace minerals in osteo- 
porosis. J Am Coll Nutr 1993;12:384-9. https://doi.org/10.1 080/07315724.1993.10718327

8. Reid DM, New SA. Nutritional influences on bone mass. Proc Nutr Soc 1997;56:977-87. https://doi.org/10.1079/PNS 19970103

9. Palacios $\mathrm{C}$. The role of nutrients in bone health, from $\mathrm{A}$ to $\mathrm{Z}$. Crit Rev Food Sci Nutr 2006;46:621-8. https://doi.org/10. 1080/10408390500466174

10. Peacock M. Calcium metabolism in health and disease. Clin J Am Soc Nephrol 2010;5(Suppl 1):S23-30. https://doi.org/ 10.2215/CJN.05910809

11. Shapiro R, Heaney RP. Co-dependence of calcium and phosphorus for growth and bone development under conditions of varying deficiency. Bone 2003;32:532-40. https://doi.org/ 10.1016/S8756-3282(03)00060-7

12. Lagos LV, Lee SA, Fondevila G, et al. Influence of the concentration of dietary digestible calcium on growth performance, bone mineralization, plasma calcium, and abundance of genes involved in intestinal absorption of calcium in pigs from 11 to $22 \mathrm{~kg}$ fed diets with different concentrations of digestible phosphorus. J Anim Sci Biotechnol 2019;10:47. https://doi.org/10.1186/s40104-019-0349-2

13. Tanck E, Homminga J, Van Lenthe GH, Huiskes R. Increase in bone volume fraction precedes architectural adaptation in growing bone. Bone 2001;28:650-4. https://doi.org/10. 1016/S8756-3282(01)00464-1

14. Sommerville BA, Maunder E, Ross R, Care AD, Brown RC. Effect of dietary calcium and phosphorus depletion on vitamin $\mathrm{D}$ metabolism and calcium binding protein in the growing pig. Horm Metab Res 1985;17:78-81. https://doi.org/10.1055/ s-2007-1013456

15.Eklou-Kalonji E, Zerath E, Colin C, et al. Calcium-regulating hormones, bone mineral content, breaking load and trabecular remodeling are altered in growing pigs fed calcium-deficient diets. J Nutr 1999;129:188-93. https://doi.org/10.1093/jn/129. 1.188

16.Sørensen KU, Tauson AH, Poulsen HD. Long term differentiated phosphorus supply from below to above requirement affects nutrient balance and retention, body weight gain and bone growth in growing-finishing pigs. Livest Sci 2018;211: 14-20. https://doi.org/10.1016/j.livsci.2018.03.002

17. Heyer CME, Weiss E, Schmucker S, et al. The impact of phosphorus on the immune system and the intestinal microbiota with special focus on the pig. Nutr Res Rev 2015;28:67-82. https://doi.org/10.1017/S0954422415000049

18. Takayanagi H. Osteoimmunology: Shared mechanisms and crosstalk between the immune and bone systems. Nat Rev Immunol 2007;7:292-304. https://doi.org/10.1038/nri2062

19. Dacey MJ. Hypomagnesemic disorders. Crit Care Clin 2001; 17:155-73. https://doi.org/10.1016/S0749-0704(05)70157-3

20. Uwitonze AM, Razzaque MS. Role of magnesium in vitamin D activation and function. J Am Osteopath Assoc 2018;118:
181-9. https://doi.org/10.7556/jaoa.2018.037

21. Brown SE. Key minerals for bone health - magnesium. Bone nutrition [Internet]. c2014 [cited 2019, Oct, 15]. Available from https:/www.betterbones.com/bone-nutrition/magnesium/

22. Rude RK, Singer FR, Gruber HE. Skeletal and hormonal effects of magnesium deficiency. J Am Coll Nutr 2009;28:131-41. https://doi.org/10.1080/07315724.2009.10719764

23.Mahdavi-Roshan M, Ebrahimi M, Ebrahimi A. Copper, magnesium, zinc and calcium status in osteopenic and osteoporotic post-menopausal women. Clin Cases Miner Bone Metab 2015; 12:18-21. https://doi.org/10.11138/ccmbm/2015.12.1.018

24.Zheng J, Mao X, Ling J, He Q, Quan J. Low serum levels of zinc, copper, and iron as risk factors for osteoporosis: a metaanalysis. Biol Trace Elem Res 2014;160:15-23. https://doi.org/ 10.1007/s12011-014-0031-7

25. Aaseth J, Boivin G, Andersen O. Osteoporosis and trace elements - an overview. J Trace Elem Med Biol 2012;26:14952. https://doi.org/10.1016/j.jtemb.2012.03.017

26. Rondanelli M, Opizzi A, Perna S, Faliva MA. Update on nutrients involved in maintaining healthy bone. Endocrinol Nutr 2013;60:197-210. https://doi.org/10.1016/j.endonu.2012. 09.006

27. Bost M, Houdart S, Oberli M, Kalonji E, Huneau JF, Margaritis I. Dietary copper and human health: current evidence and unresolved issues. J Trace Elem Med Biol 2016;35:107-15. https://doi.org/10.1016/j.jtemb.2016.02.006

28. Patrick L. Comparative absorption of calcium sources and calcium citrate malate for the prevention of osteoporosis. Altern Med Rev 1999;4:74-85.

29. Rico H, Roca-Botran C, Hernandez ER, et al. The effect of supplemental copper on osteopenia induced by ovariectomy in rats. Menopause 2000;7:413-6. https://doi.org/10.1097/ 00042192-200011000-00007

30.Pietak AM, Reid JW, Stott MJ, Sayer M. Silicon substitution in the calcium phosphate bioceramics. Biomaterials 2007;28: 4023-32. https://doi.org/10.1016/j.biomaterials.2007.05.003

31.Incharoen T, Tartrakoon W, Nakhon S, Treetan S. Effects of dietary silicon derived from rice hull ash on the meat quality and bone breaking strength of broiler chickens. Asian J Anim Vet Adv 2016;11:417-22. https://doi.org/10.3923/ajava.2016. 417.422

32. Reffitt DM, Ogston N, Jugdaohsingh R, et al. Orthosilicic acid stimulates collagen type 1 synthesis and osteoblastic differentiation in human osteoblast-like cells in vitro. Bone 2003;32: 127-35. https://doi.org/10.1016/S8756-3282(02)00950-X

33. Jugdaohsingh R. Silicon and bone health. J Nutr Health Aging 2007;11:99-110.

34. Boguszewska-Czubara A, Pasternak K. Silicon in medicine and therapy. J Elem 2011;16:489-97. https://doi.org/10.5601/ jelem.2011.16.3.13

35. Maehira F, Miyagi I, Eguchi Y. Effects of calcium sources and soluble silicate on bone metabolism and the related gene 
expression in mice. Nutrition 2009;25:581-9. https://doi.org/ 10.1016/j.nut.2008.10.023

36. Short FE, Burton E, Belton D, Mann G, Perry C. Efficacy of a novel form of dietary silicon supplement in reducing lameness in poultry. Br Poult Abstr 2011;7:1-2.

37.Nakhon S, Numthuam S, Charoensook R, Tartrakoon W, Incharoen P, Incharoen T. Growth performance, meat quality, and bone-breaking strength in broilers fed dietary rice hull silicon. Anim Nutr 2019;5:152-5. https://doi.org/10.1016/j. aninu.2018.11.003

38. Volpe S, Taper LJ, Meacham S. The relationship between boron and magnesium status and bone mineral density in the human: a review. Magnes Res 1993;6:291-6.

39.Penland JG. Dietary boron, brain function, and cognitive performance. Environ Health Perspect 1994;102(Suppl 7):S6572. https://doi.org/10.1289/ehp.94102s765

40.Institute of Medicine. Dietary reference intakes for vitamin A, vitamin $\mathrm{K}$, arsenic, boron, chromium, copper, iodine, iron, manganese, molybdenum, nickel, silicon, vanadium, and zinc. Washington, DC, USA: The National Academies Press; 2001. https://doi.org/10.17226/10026

41.Chapin RE, Ku WW, Kenney MA, McCoy H. The effects of dietary boric acid on bone strength in rats. Biol Trace Elem Res 1998;66:395-9. https://doi.org/10.1007/BF02783150

42. Wilson JH, Ruszler PL. Long term effects of boron on layer bone strength and production parameters. Br Poult Sci 1998; 39:11-5. https://doi.org/10.1080/00071669889312

43. Holick MF. Sunlight, ultra violet radiation, vitamin D, and skin cancer: how much sunlight do we need? In: Reichrath J. editor. Sunlight, vitamin D and skin cancer. New York, USA: Springer-Verlag; 2014. pp. 1-16. https://doi.org/10.1007/9781-4939-0437-2

44. Cashman KD, Seamans KM, Lucey AJ, et al. Relative effectiveness of oral 25-hydroxyvitamin D3 and vitamin $\mathrm{D}_{3}$ in raising wintertime serum 25-hydroxyvitamin $\mathrm{D}$ in older adults. Am J Clin Nutr 2012;95:1350-6. https://doi.org/10. 3945/ajcn.111.031427

45.Driver JP, Pesti GM, Bakalli RI, Edwards HM, Jr. Calcium requirements of the modern broiler chicken as influenced by dietary protein and age. Poult Sci 2005;84:1629-39. https:// doi.org/10.1093/ps/84.10.1629

46. Norman AW. The vitamin D endocrine system. Physiologist 1985;28:219-32.

47. Holick MF. Vitamin D: evolutionary, physiological and health perspectives. Curr Drug Targets 2011;12:4-18. https://doi. org/10.2174/138945011793591635

48. Razzaque MS. The dualistic role of vitamin D in vascular calcifications. Kidney Int 2011;79:708-14. https://doi.org/ 10.1038/ki.2010.432

49. Fritts CA, Waldroup PW. Effect of source and level of vitamin $\mathrm{D}$ on live performance and bone development in growing broilers. J Appl Poult Res 2003;12:45-52. https://doi.org/10. 1093/japr/12.1.45

50. Garcia AFQM, Murakami AE, Duarte CRA, Rojas ICO, Picoli KP, Puzotti MM. Use of vitamin D3 and its metabolites in broiler chicken feed on performance, bone parameters and meat quality. Asian-Australas J Anim Sci 2013;26:408-15. https://doi.org/10.5713/ajas.2012.12455

51.Amundson LA. Insights into nutrient inputs that affect the initiation of bone lesions in pigs. J Anim Sci 2016;94(Suppl_2): 123.

52. Garcia LA, King KK, Ferrini MG, Norris KC, Artaza JN. $1,25(\mathrm{OH})_{2}$ vitamin $\mathrm{D}_{3}$ stimulates myogenic differentiation by inhibiting cell proliferation and modulating the expression of promyogenic growth factors and myostatin in $\mathrm{C}_{2} \mathrm{C}_{12}$ skeletal muscle cells. Endocrinology 2011;152:2976-86. https://doi. org/10.1210/en.2011-0159

53. DeLuca HF. Vitamin D: the vitamin and the hormone. Fed Proc 1974;33:2211-9.

54.Dodds RA, Catterall A, Bitensky L, Chayen J. Abnormalities in fracture healing induced by vitamin B6-deficiency in rats. Bone 1986;7:489-95. https://doi.org/10.1016/8756-3282(86) 90008-6

55. Masse PG, Pritzker KP, Mendes MG, Boskey AL, Weiser H. Vitamin B6 deficiency experimentally-induced bone and joint disorder: Microscopic, radiographic and biochemical evidence. Br J Nutr 1994;71:919-32. https://doi.org/10.1079/ bjn19940196

56. Herrmann M, Wildemann, B, Wagner A, et al. Experimental folate and vitamin B12 deficiency does not alter bone quality in rats. J Bone Miner Res 2009;24:589-96. https://doi.org/10. 1359/jbmr.081211

57. Holstein JH, Herrmann M, Schmalenbach J, et al. Deficiencies of folate and vitamin B12 do not affect fracture healing in mice. Bone 2010;47:151-5. https://doi.org/10.1016/j.bone. 2010.04.592

58. Neve A, Corrado A, Cantatore FP. Osteocalcin: skeletal and extra-skeletal effects. J Cell Physiol 2013;228:1149-53. https:// doi.org/10.1002/jcp.24278

59. Cancela L, Hsieh CL, Francke U, Price PA. Molecular structure, chromosome assignment, and promoter organization of the human matrix Gla protein gene. J Biol Chem 1990;265: 15040-8.

60.Lombardi G, Perego S, Luzi L, Banfi G. A four-season molecule: osteocalcin. Updates in its physiological roles. Endocrine 2015;48:394-404. https://doi.org/10.1007/s12020-014-0401-0

61. Akbari S, Rasouli-Ghahroudi AA. Vitamin K and bone metabolism: A review of the latest evidence in preclinical studies. Biomed Res Int 2018;2018:4629383. https://doi.org/10.1155/ 2018/4629383

62.Schonfeldt HC, Pretorius B, Hall N. Bioavailability of nutrients. In: Caballero B, Finglas PM, Toldrá F, editors. Encyclopedia of food and health. Oxford, UK: Academic Press; 2016. pp. 401-6. https://doi.org/10.1016/B978-0-12-384947-2.00068-4 
63. Saura-Calixto F, Serrano J, Goni I. Intake and bioaccessibility of total polyphenols in a whole diet. Food Chem 2007;101: 492-501. https://doi.org/10.1016/j.foodchem.2006.02.006

64. Gropper SS, Smith JL. The digestive system: mechanism for nourishing the body. In: Gropper SS, Smith JL, Groff JL, editors. Advanced nutrition and human metabolism. 5th ed. Belmont, CA, USA: Wadsworth, Cengage Learning; 2009. pp. 33-62.

65. Ma YL, Lindemann MD, Webb SF, Rentfrow G. Evaluation of trace mineral source and preharvest deletion of trace minerals from finishing diets on tissue mineral status in pigs. AsianAustralas J Anim Sci 2018;31:252-62. https://doi.org/10. 5713/ajas.17.0189

66. Li KX, Wang JS, Yuan D, Zhao RX, Wang YX, Zhan XA. Effects of different selenium sources and levels on antioxidant status in broiler breeders. Asian-Australas J Anim Sci 2018;31:193945. https://doi.org/10.5713/ajas.18.0226

67.Xu H, Dai S, Zhang K, et al. Dietary phosphorus deficiency impaired growth, intestinal digestion and absorption function of meat ducks. Asian-Australas J Anim Sci 2019;32:1897-906. https://doi.org/10.5713/ajas.18.0683

68. Pressman P, Clemens RA, Hayes AW. Bioavailability of micronutrients obtained from supplements and food: A survey and case study of the polyphenols. Toxicol Res Appl 2017;1: 1-7. https://doi.org/10.1177/2397847317696366

69. Fairweather-Tait, Southoun S. Bioavailability of nutrients. In: Caballero B, Trugo LC, Finglas PM, editors. Encyclopedia of food sciences and nutrition 2nd ed. London, UK: Academic Press; 2003. p. 478-84.

70.Hill CH, Matrone G. Chemical parameters in the study of in vivo and in vitro interactions of transition elements. Fed Proc 1970;29:1474-81.

71. Hambridge KM. Micronutrient bioavailability: Dietary reference intakes and a future perspective. Am J Clin Nutr 2010; 91:1430S-2S. https://doi.org/10.3945/ajcn.2010.28674B

72. Truswell AS. Vitamin B12. Nutr Diet 2007;64(Suppl 4):S1205. https://doi.org/10.1111/j.1747-0080.2007.00198.x

73. Singh OV. Bio-nanoparticles: biosynthesis and sustainable biotechnological implications. Hoboken, NJ, USA: WileyBlackwell; 2015.

74. Shukla A, Iravani S. Green synthesis, characterization and applications of nanoparticles. Amsterdam, The Netherlands: Elsevier; 2018.

75. Oehlke K, Adamiuk M, Behsnilian D, et al. Potential bioavailability enhancement of bioactive compounds using foodgrade engineered nanomaterials: a review of the existing evidence. Food Funct 2014;5:1341-59. https://doi.org/10. 1039/c3fo60067j

76. Jampliek J, Kos J, Kralova K. Potential of nanomaterial applications in dietary supplements and foods for special medical purposes. Nanomaterials 2019;9:296. https://doi.org/10.3390/ nano9020296
77.Sharma S, Jaiswal S, Duffy B, Jaiswal AK. Nanostructured materials for food applications: spectroscopy, microscopy and physical properties. Bioengineering 2019;6:26. https:// doi.org/10.3390/bioengineering6010026

78. Gonnet M, Lethuaut L, Boury F. New trends in encapsulation of liposoluble vitamins. J Control Release 2010;146:27690. https://doi.org/10.1016/j.jconrel.2010.01.037

79. Reza Mozafari M, Johnson C, Hatziantoniou S, Demetzos C. Nanoliposomes and their applications in food nanotechnology. J Liposome Res 2008;18:309-27. https://doi.org/10.1080/0898 2100802465941

80. Ghosh I, Bose S, Vippagunta R, Harmon F. Nanosuspension for improving the bioavailability of a poorly soluble drug and screening of stabilizing agents to inhibit crystal growth. Int J Pharm 2011;409:260-8. https://doi.org/10.1016/j.ijpharm. 2011.02.051

81. Joye IJ, Davidov-Pardo G, McClements DJ. Nanotechnology for increased micronutrient bioavailability. Trends Food Sci Technol 2014;40:168-82. https://doi.org/10.1016/j.tifs.2014. 08.006

82. Öztürk B. Nanoemulsions for food fortification with lipophilic vitamins: production challenges, stability, and bioavailability. Eur J Lipid Sci Technol 2017;119:1500539. https://doi.org/10. 1002/ejlt.201500539

83. Debski B. Supplementation of pigs diet with zinc and copper as alternative to conventional antimicrobials. Pol J Vet Sci 2016;19:917-24. https://doi.org/10.1515/pjvs-2016-0113

84.Xia T, Lai W, Han M, Han M, Ma X, Zhang L. Dietary ZnO nanoparticles alter intestinal microbiota and inflammation response in weaned piglets. Oncotarget 2017;8:64878-91. https://doi.org/10.18632/oncotarget.17612

85. Upadhaya SD, YM Kim, KY Lee, IH Kim. Use of protected zinc oxide in lower doses in weaned pigs in substitution for the conventional high dose zinc oxide. Anim Feed Sci Technol 2018;240:1-10. https://doi.org/10.1016/j.anifeedsci.2018. 03.012

86. Vahjen W, Zentek J, Durosoy S. Inhibitory action of two zinc oxide sources on the ex vivo growth of porcine small intestine bacteria. J Anim Sci 2012;90:334-6. https://doi.org/10.2527/ jas. 52921

87. Cho JH, Upadhaya SD, Kim IH. Effects of dietary supplementation of modified zinc oxide on growth performance, nutrient digestibility, blood profiles, fecal microbial shedding and fecal score in weanling pigs. Anim Sci J 2015;86:617-23. https:// doi.org/10.1111/asj.12329

88. Ammerman CB, Baker DH, Lewis AJ. Bioavailability of nutrients for animals: amino acids, minerals, and vitamins. San Diego, CA, USA: Academic Press; 1995.

89. Baker DH. Bioavailability of minerals and vitamins. In: Lewis AJ, Southern LL, editors. Swine nutrition. Boca Raton, FL, USA: CRC Press; 2001. pp. 357-79.

90. Baker DH. Cupric oxide should not be used as a copper supple- 
ment for either animals or humans. J Nutr 1999;129:227879. https://doi.org/10.1093/jn/129.12.2278

91. Ashmead HD, Graff DJ, Ashmead HH. Intestinal absorption of metal ions and chelates. Springfield, IL, USA: Thomas CC; 1985. pp. 118-25.

92.Jiao Y, Li X, Kim IH. Changes in growth performance, nutrient digestibility, immune blood profiles, fecal microbial and fecal gas emission of growing pigs in response to zinc aspartic acid chelate. Asian-Australas J Anim Sci 2020;33:597-604. https://doi.org/10.5713/ajas.19.0057

93. Cao J, Henry PR, Davis SR, et al. Relative bioavailability of organic zinc sources based on tissue zinc and metallothionein in chicks fed conventional dietary zinc concentrations. Anim Feed Sci Technol 2002;101:161-70. https://doi.org/10.1016/ S0377-8401(02)00051-2

94.Guo HH, Hong ZA, Yi RZ. Core-shell collagen peptide chelated calcium/calcium alginate nanoparticles from fish scales for calcium supplementation. J Food Sci 2015;80:N1595601. https://doi.org/10.1111/1750-3841.12912

95. Chen J, Qiu X, Hao G, Zhang M, Weng W. Preparation and bioavailability of calcium-chelating peptide complex from tilapia skin hydrolysates. J Sci Food Agric 2017;97:4898-903. https://doi.org/10.1002/jsfa.8363

96. Yi G, Atwell C, Hume J, Dibner J, Knight C, Richards J. Determining the methionine activity of Mintrex organic trace minerals in broiler chicks by using radiolabel tracing or growth assay. Poult Sci 2007;86:877-87. https://doi.org/10. 1093/ps/86.5.877

97.Sun Q, Guo Y, Li J, Zhang T, Wen J. Effects of methionine hydroxy analog chelated $\mathrm{Cu} / \mathrm{Mn} / \mathrm{Zn}$ on laying performance, egg quality, enzyme activity and mineral retention of laying hens. J Poult Sci 2012;49:20. https://doi.org/10.2141/jpsa. 011055

98. Manangi MK, Hampton T, Fisher P, Richards JD, VazquezAnon M, Christensen KD. Impact of feeding lower levels of chelated trace minerals vs. industry levels of inorganic trace minerals on broiler performance, yield, footpad health, and litter mineral concentration. J Appl Poult Res 2012;21:88190. https://doi.org/10.3382/japr.2012-00531

99. DSM Nutritional Products Limited. Optimum vitamin nutrition: in the production of quality animal foods. Benchmark House, UK: 5m Publishing; 2012.

100. Lin H, Wang LF, Song JL, Xie YM, Yang QM. Effect of dietary supplemental levels of vitamin a on the egg production and immune responses of heat-stressed laying hens. Poult Sci
2002;81:458-65. https://doi.org/10.1093/ps/81.4.458

101. Mattila P, Valaja J, Rossow L, Venalainen E, Tupasela T. Effect of vitamin D2- and D3- enriched diets on egg vitamin D content, production, and bird condition during an entire production period. Poult Sci 2004;83:433-40. https://doi.org/ 10.1093/ps/83.3.433

102. Terry M, Lanenga M, McNaughton JL, Stark LE. Safety of 25-hydrioxyvitamin $\mathrm{D}_{3}$ as a source of vitamin $\mathrm{D}_{3}$ in layer poultry feed. Vet Hum Toxicol 1999;41:312-6.

103. Bollengier-Lee S, Mitchell MA, Utomo DB, Williams PEV, Whitehead CC. Influence of high dietary vitamin E supplementation on egg production and plasma characteristics in hens subjected to heat stress. Br Poult Sci 1998;39:106-12. https://doi.org/10.1080/00071669889466

104. Fleming RH, McCormack HA, Whitehead CC. Bone structure and strength at different ages in laying hens and effects of dietary particulate limestone, vitamin $\mathrm{K}$ and ascorbic acid. Br Poult Sci 1998;39:434-40. https://doi.org/10.1080/000716 69889024

105. Squires MW, Naber EC. Vitamin profiles of eggs as indicators of nutritional status in the laying hen: riboflavin study. Poult Sci 1993;72:483-94. https://doi.org/10.3382/ps.0720483

106. Weiser H, Schlachter M, Probst HP, Flachowsky G, Schone F. Importance of vitamin D3, C and B6 for bone metabolism. Friedrich Schiller Universitat Jena Germany. Vitamins and other additives in humans and animals. 3rd Symposium 1991; Jena, Germany. p. 26-7.

107. Dikicioglu T, Yigit AA, Ozdemir, E. The effects of niacin on egg production and egg quality. Lalahan Hay Arast Enst Derg 2000;40:65-74.

108. Liu A, Feng L. Effects of supplementation of folic acid, ascorbic acid and cyanocobalamin on the performance of layers. Ningxia J Agro-For Sci Technol 1992;6:40-2.

109. Orban JI, Roland DA, Cummins K, Lovell RT. Influence of large doses of ascorbic acid on performance, plasma calcium, bone characteristics, and eggshell quality in broilers and Leghorn hens. Poult Sci 1993;72:691-700. https://doi.org/10. 3382/ps.0720691

110. de Mendonca Jr CX, Guerra EM, Oliveria CA. Choline supplementation for Hisex Brown and Hisex White laying hens. 2. Liver lipid deposition and plasma lipids levels. Rev Fac Med Vet Zootec Univ S Paulo (Brazil) 1989;26:93-103.

111. National Research Council. Nutrient requirements of swine. 11th ed. Washington, DC, USA: National Academy Press; 2012. 